\title{
In vitro antifungal activity of four chemotypes of Lippia alba (Verbenaceae) essential oils against Alternaria solani (Pleosporeaceae) isolates
}

\author{
ELISA Z. TOMAZONI, MÁRCIA R. PANSERA, GABRIEL F. PAULETTI, SIDNEI \\ MOURA, RUTE T.S. RIBEIRO and JOSÉLI SCHWAMBACH \\ Instituto de Biotecnologia, Universidade de Caxias do Sul, Rua Francisco Getúlio \\ Vargas, 1130, Petrópolis, 95070-560 Caxias do Sul, RS, Brasil
}

Manuscript received on January, 13, 2015; accepted for publication on May 15, 2015

\begin{abstract}
Several volatile natural compounds produced by plant secondary metabolism have been proven to present antimicrobial action, enabling their use in phytopathogen control. They also present low environmental impact when compared to conventional pesticides. Essential oils contain these compounds and can be found in several plant species, such as Lippia alba (Mill.) N.E. Brown (Verbenaceae). Essential oils of four chemotypes of $L$. alba, characterized by their major compounds, namely camphor, citral, linalool and camphor/1,8-cineole, were tested against the phytopathogen Alternaria solani Sorauer (Pleosporaceae), which causes early blight on tomatoes and is responsible for great economic losses regarding production. Essential oils antifungal action was tested in vitro using potato dextrose agar medium with essential oil concentrations at $0.1,0.5,1.0,1.5$ and $2.0 \mu \mathrm{L} \mathrm{mL}^{-1}$. The chemotype that had the best performance was citral, showing significant inhibition compared to the others, starting at the $0.5 \mu \mathrm{L} \mathrm{mL}^{-1}$ concentration. The essential oil belonging to the linalool chemotype was efficient starting at the $1.5 \mu \mathrm{L} \mathrm{mL}^{-1}$ concentration. Conversely, the camphor chemotype did not show any action against the phytopathogen. Moreover, the essential oils had no remarkable effect on tomato germination and growth. In conclusion, these essential oils presented fungicidal action against $A$. solani.
\end{abstract}

Key words: citral, early blight, natural product, phytopathogen.

\section{INTRODUCTION}

The tomato (Lycopersicon esculentum Mill.) crop is cultivated worldwide. It has a major role in global economy due to its production volume and value, being the second most cultivated vegetable, after the potato crop (Figueira 2000). However, it is host to more than two hundred diseases caused by biotic and abiotic agents that contribute to a significant

Correspondence to: Joséli Schwambach

E-mail: joselischwambach@gmail.com decrease in its productivity (Lopes and Santos 1994). One of the most frequent diseases of the tomato crop is early blight, caused by Alternaria solani Sorauer. This disease occurs on leaves, stems and fruits, and causes considerable economic losses (Kurozawa and Pavan 2005).

The main method used to control early blight concerns the application of synthetic fungicides. However, the use of fungicides increases not only production costs, but also the risk of environment contamination; it also leads to health problems 
in workers and consumers and selects resistant pathogens (Kishore and Pande 2007). Therefore, developing alternatives for the control of fungal diseases is necessary in order to reduce this dependence on chemical fungicides.

Essential oils are plant natural products, which have great potential as a substitute to the use of synthetic fungicides, since they have antifungal, antibacterial and insecticidal properties (Feng and Zheng 2007). These natural compounds are less harmful to humans, compared to synthetic products, and less toxic to the environment due to compound volatilization (Satish et al. 2007). Besides, the majority of essential oils are classified as Generally Recognized as Safe and present low risk with regard to the development of resistance by pathogenic microorganisms. Essential oils are complex mixtures of volatile organic substances, consisting, for the most part, of oxygenated compounds and hydrocarbons, such as sesquiterpenes and terpenes, the latter being predominant. The composition of essential oils varies among plant species and even in the same species, enabling them to present different biological activities (Nerio et al. 2010). The antimicrobial action of essential oils occurs due to the presence of terpenoids and phenolic compounds in their structures, given that they present a lipophilic nature. These compounds interact with microbial membranes and disrupt the permeability barrier, leading to the leakage of cell content and impairing energy production (Tian et al. 2012). In this context, using essential oils would be of great advantage to the development of new products for the control of plant diseases.

Native plants are often used as natural drugs by local populations, characterizing them as phytotherapic plants due to their curative and medicinal action (Khan et al. 2009). Lippia alba (Mill.) N. E. Brown is one of the medicinal plant species found in Brazil, among other countries in Latin America, and is widely employed due to its sedative, carminative, analgesic and spasmolytic properties (Hennebelle et al. 2008). Nonetheless, it also has antimicrobial and fungicidal activity associated to its essential oils, affecting several microorganisms (Zétola et al. 2002). However, wild populations differ in essential oil composition both quantitatively and qualitatively, which enables them to be separated into chemotypes (Tavares et al. 2005). Manica-Cattani et al. (2009) developed a study with twenty-seven different accessions of Lippia alba from Southern Brazil, which were collected and cultivated in order to identify their chemotypes. Gas chromatographic analyses of their essential oils revealed seven different chemotypes, given that most compounds pertained to the monoterpene type.

This study evaluates and compares the effectiveness and the inhibitory effect of essential oils obtained from four chemotypes of $L$. alba against the phytopathogen $A$. solani, under in vitro conditions.

\section{MATERIALS AND METHODS}

\section{PLANT MATERIAL}

Leaves of four different accessions of Lippia alba (Mill.) N. E. Brown were harvested from plants of the germplasm collection of the Institute of Biotechnology, University of Caxias do Sul, RS, Brazil, and voucher specimens were deposited at the Herbarium of the University of Caxias do Sul (HUCS) The accessions were named according to the cities from which they were obtained, in Southern Brazil (Manica-Cattani et al. 2009): Teutônia - RS (HUCS26633 original and HUCS39706 cultivated), Pelotas - RS (HUCS26631 original and HUCS39707 cultivated), Caxias do Sul - RS (HUCS24689 original and HUCS39705 cultivated) and Santa Vitória do Palmar - RS (HUCS32197 original and HUCS39704 cultivated).

\section{ESSENTIAL OIL EXTRACTION AND CHEMICAL IDENTIFICATION}

The essential oils were extracted by hydrodistillation method from the dried plant leaves for $1 \mathrm{~h}$ in 
a Clevenger-type apparatus according to Agostini et al. (2009). For chemical identification, a gas chromatograph HP 6890 coupled with a mass selective detector Hewlett Packard MSD5973 (GC-MS), equipped with HP Chemstation software and Wiley 275 spectra data was used to perform the analyses. The analyses were conducted using a fused silica capillary column HP-Innowax (30 $\mathrm{m} \times 0.25 \mathrm{~mm}$ i.d., $0.25 \mu \mathrm{m}$ film thickness, Hewlett Packard, Palo Alto, USA) with the following conditions: column temperature, $40{ }^{\circ} \mathrm{C}(8 \mathrm{~min})$ to $180{ }^{\circ} \mathrm{C}$ at $3{ }^{\circ} \mathrm{C} / \mathrm{min}, 180-230{ }^{\circ} \mathrm{C}$ at $20{ }^{\circ} \mathrm{C} / \mathrm{min}, 230$ ${ }^{\circ} \mathrm{C}$ (20 min); interface $280^{\circ} \mathrm{C}$; split ratio $1: 100$; carrier gas $\mathrm{He}(56 \mathrm{KPa})$; flow rate: $1.0 \mathrm{~mL} / \mathrm{min}$; ionization energy $70 \mathrm{eV}$; mass range 40-350. The volume injected was $0.4 \mu \mathrm{L}$ (diluted in hexane 1:10). Analytical gas chromatography was carried out in a Hewlett Packard 6890 gas chromatograph with a flame ionization detector (FID) equipped with a HP Chemstation software. A HP-Innowax bonded phase capillary column $(30 \mathrm{~m} \times 0.32 \mathrm{~mm}$ i.d., $0.50 \mu \mathrm{m}$ film thickness, Hewlett Packard, Palo Alto, USA) was used with the following conditions: column temperature, $40{ }^{\circ} \mathrm{C}(8 \mathrm{~min})$ to $180{ }^{\circ} \mathrm{C}$ at 3 ${ }^{\circ} \mathrm{C} / \mathrm{min}, 180-230{ }^{\circ} \mathrm{C}$ at $20^{\circ} \mathrm{C} / \mathrm{min}, 230{ }^{\circ} \mathrm{C}(20 \mathrm{~min})$; injector temperature $250{ }^{\circ} \mathrm{C}$, detector temperature $250{ }^{\circ} \mathrm{C}$; split ratio $1: 50$; carrier gas $\mathrm{H}_{2}(34 \mathrm{KPa})$. The injection volume was $1 \mu \mathrm{L}$ (diluted in hexane 1:10). Identification of the individual components was based on comparison of their GC retention times (R.T.) on polar columns and comparison with mass spectra of components by GC-MS. The components were identified by a combination of mass spectrum of the Wiley library and by comparison with data from literature (Adams 1989).

Alternaria solani ISOLATES

The isolates used in this work were isolated from tomatoes and preserved in the fungal collection of the Laboratory of Phytopathology, University of Caxias do Sul, Brazil, on Potato-Dextrose-
Agar (PDA) medium. Four A. solani isolates from tomato crops located within Southern Brazil were tested: A03/09 (Veranópolis - RS), A11/09, A13/09 (both from Vacaria - RS) and A1033 (Caxias do Sul - RS).

ANTIFUNGAL ACTIVITY OF ESSENTIAL OILS ON MYCELIAL GROWTH UNDER in vitro CONDITIONS

Microorganism development and inhibition was evaluated in different essential oil concentrations using potato dex trose agar medium(PDA) according to Feng and Zheng (2007), with minor modifications. The adopted essential oil concentrations were 0.1 , $0.5,1.0,1.5$ and $2.0 \mu \mathrm{L} \mathrm{mL}^{-1}$, with the addition of Tween 20 (1:1), diluted on autoclaved and melted PDA $\left(40{ }^{\circ} \mathrm{C}\right)$ under aseptic conditions, preparing a $100 \mathrm{~mL}$ emulsion for each concentration. These emulsions were poured into $90 \mathrm{~mm}$ diameter Petri dishes and, after medium solidification, inoculated with two $8 \mathrm{~mm}$ diameter agar disks colonized by $A$. solani mycelium from a seven-day-old culture. The control received the same quantities of Tween 20 mixed with PDA. Azoxystrobin (AmistarÒ, TopSyngenta, Basel, Switzerland) and Difenoconazol (ScoreÒ, Syngenta, Basel, Switzerland) were used as standard fungicides, following manufacturer recommendations for dosage $\left(0.08 \mathrm{~g} \mathrm{~L}^{-1}\right.$ and 0.5 $\mathrm{mL} \mathrm{L}^{-1}$, respectively). Ten replicates were used per treatment. Incubation was performed in B.O.D at a $25{ }^{\circ} \mathrm{C}$ temperature and a 12 -h photoperiod, during fourteen days. Fungal growth was recorded on the $3^{\text {rd }}, 7^{\text {th }}$ and $14^{\text {th }}$ days. Transfer experiments were performed in order to make a distinction between the fungistatic and fungicidal effects of the essential oils on the target microorganisms. For this purpose, plugs that did not grow were transferred to fresh PDA dishes and their viability and growth we assessed after seven and fourteen days of inoculation at $25^{\circ} \mathrm{C}$. The residual fungal growth was monitored by measuring the radial growth of the fungi. 
PHYTOTOXIC ACTIVITY OF ESSENTIAL OIL VOLATILES ON TOMATO SEEDS

The adopted essential oil concentrations were 0.1 , 0.15 and $0.2 \%$ aqueous emulsions (similar to the antifungal activity concentrations). The aqueous emulsions were made with the addition of a $0.1 \%$ solution of Tween 20 and autoclaved distilled water $(1: 100, v / v)$. For the germination bioassay, 20 seeds were soaked in $2.5 \mathrm{~mL}$ of autoclaved distillated water on a layer of filter paper, in Petri dishes, and incubated in B.O.D at a $25^{\circ} \mathrm{C}$ temperature and a 16-h photoperiod. Essential oil emulsions were added onto a cotton ball attached to the inner face of the Petri dish lid, allowing the oil to volatilize into the airspace within the dish. A negative control group was treated with distilled water, and five replicates of each treatment were carried out. The effect of the essential oils on germination rates was evaluated by counting the number of germinated seeds after seven days of bioassay. Seeds that were considered as germinated had 2 to $3 \mathrm{~mm}$ of root length. Regarding the plant growth bioassay, 10 pre-germinated seeds in distilled water, under the same conditions of the germination assay, were used for each Petri dish and five replicates were performed for each treatment. Essential oil emulsions were applied, as in the germination test, after the emergence of the primary root. The seedlings remained exposed to essential oil volatiles for seven days and were then evaluated by measuring the hypocotyl and root length.

\section{STATISTICAL ANALYSES}

Variance analyses (ANOVA) followed by Tukey test, when appropriate $(\mathrm{p} \leq 0.05)$, were performed for all parameters, using the SPSS statistical software (SPSS for Windows v.19.0).

\section{RESULTS}

\section{CHEMICAL COMPOSITION OF THE ESSENTIAL OILS}

Oils extracted from dried leaves of $L$. alba yielded

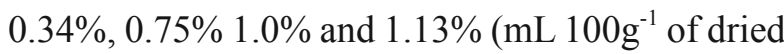
leaves) for the accessions of Teutônia, Pelotas, Caxias do Sul and Santa Vitória do Palmar, respectively. Major compounds of essential oils for each $L$. alba accession were: Teutônia - geranial (34.28\%) and neral (25.44\%), characterizing it as a citral chemotype; Pelotas - camphor (30.66\%) and 1,8-cineole $(22.99 \%)$, characterizing it as a camphor/1,8-cineole chemotype; Caxias do Sul linalool $(53.37 \%)$, characterizing it as a linalool chemotype; Santa Vitória do Palmar - camphor (51.97\%), characterizing it as a camphor chemotype (Table I).

TABLE I

Major chemical compounds of four chemotypes of Lippia alba essential oils.

\begin{tabular}{|c|c|c|c|c|c|}
\hline \multirow{2}{*}{ Compounds } & \multicolumn{5}{|c|}{ Concentrations (\%) } \\
\hline & *RT (min) & Teutônia & Pelotas & Caxias do Sul & Santa Vitória do Palmar \\
\hline Monoterpenoid Hidrocarbons & & - & 13.01 & 1.92 & 24.15 \\
\hline$\alpha$-pinene & 3.54 & - & 0.57 & - & 1.54 \\
\hline$\gamma$-terpinene & 4.13 & - & 6.94 & - & - \\
\hline camphene & 4.51 & - & 2.05 & - & 7.07 \\
\hline$\beta$-pinene & 7.98 & - & - & - & 1.02 \\
\hline$\beta$-myrcene & 8.91 & - & 3.45 & - & 8.50 \\
\hline sabinene & 13.44 & - & - & 0.57 & - \\
\hline limonene & 16.18 & - & - & 1.35 & 5.19 \\
\hline$\alpha$-terpinolene & 20.71 & - & - & - & 0.83 \\
\hline
\end{tabular}


TABLE I (continuation)

\begin{tabular}{|c|c|c|c|c|c|}
\hline \multirow{2}{*}{ Compounds } & & \multicolumn{4}{|c|}{ Concentrations $(\%)$} \\
\hline & *RT (min) & Teutônia & Pelotas & Caxias do Sul & Santa Vitória do Palmar \\
\hline Oxygenated Monoterpenes & & 76.45 & 55.17 & 59.67 & 59.31 \\
\hline 1,8-cineole & 9.93 & 2.70 & 22.99 & 4.23 & - \\
\hline pinocarvon & 23.80 & - & 1.52 & - & - \\
\hline camphor & 27.83 & - & 30.66 & - & 51.97 \\
\hline linalool oxide & 30.54 & - & - & 0.27 & - \\
\hline linalool & 31.52 & 10.85 & - & $\mathbf{5 3 . 3 7}$ & 4.06 \\
\hline neral & 35.16 & 25.44 & - & 0.52 & - \\
\hline geranial & 37.03 & 34.28 & - & 1.28 & - \\
\hline verbenone & 41.89 & - & - & - & 1.20 \\
\hline borneol & 42.10 & - & - & - & 1.53 \\
\hline$\rho$-cimen-8-ol & 47.72 & - & - & - & 0.55 \\
\hline geranic acid & 50.75 & 3.18 & - & - & - \\
\hline Sesquiterpens Hidrocarbons & & - & 6.16 & 11.81 & 3.23 \\
\hline$\beta$-caryophyllene & 25.26 & - & 2.69 & - & - \\
\hline trans- $\beta$-caryophyllene & 37.29 & - & - & 2.77 & 2.07 \\
\hline$\beta$-elemene & 37.32 & - & - & 1.21 & - \\
\hline$\alpha$-humulene & 40.55 & - & - & 0.43 & - \\
\hline trans- $\beta$-farnesene & 41.17 & - & - & 0.82 & - \\
\hline germacrene D & 42.22 & - & - & 3.33 & - \\
\hline germacrene B & 42.48 & - & 3.47 & 3.25 & 1.16 \\
\hline Oxygenated Sesquiterpens & & 8.34 & 8.18 & 6.02 & 1.00 \\
\hline 1,6-germacradien-5-ol & 41.78 & - & 8.18 & - & - \\
\hline caryophyllene oxide & 47.97 & 7.80 & - & 3.58 & 1.00 \\
\hline nerolidol & 54.48 & - & - & 0.90 & - \\
\hline spathulenol & 56.03 & - & - & 0.82 & - \\
\hline humulene oxide & 56.59 & - & - & 0.72 & - \\
\hline farnesol & 57.70 & 0.54 & - & - & - \\
\hline
\end{tabular}

*RT: Retention time obtained by chromatogram.

\section{ANTIFUNGAL ACTIVITY OF THE ESSENTIAL OILS}

A significant inhibitory effect was observed for essential oils of the citral, camphor/1,8-cineole and linalool chemotypes. The exception was the camphor chemotype, which did not inhibit any of the $A$. solani isolates. Moreover, the inhibitory effect of essential oils differed with regard to the $A$. solani isolates and tested concentrations (Fig. 1). However, all essential oils presented a time course action from the third to the fourteenth day after inoculation and depended on the concentration. The effect was observed from the third day after inoculation, with the lowest concentration $\left(0.1 \mu \mathrm{L} \mathrm{mL} \mathrm{m}^{-1}\right)$. After the third day, the fungi isolates surpassed the inhibitory effect of the low concentration of essential oils and succeeded to grow, therefore, higher concentrations were necessary for a successful inhibition. Data obtained on the $14^{\text {th }}$ day of assay showed that the essential oils were effective at inhibiting the mycelial growth of $A$. solani, maintaining their action during this period (data not shown).

The citral chemotype essential oil showed total inhibition on the $7^{\text {th }}$ day, starting at the $1.0 \mu \mathrm{L} \mathrm{mL}^{-1}$ concentration for A03/09 and A11/09, however, A13/09 demanded a higher minimum concentration $\left(1.5 \mu \mathrm{L} \mathrm{mL}^{-1}\right)$. The $0.5 \mu \mathrm{L} \mathrm{mL}^{-1}$ concentration presented fungicidal action for A1033 (Fig. 1a). 

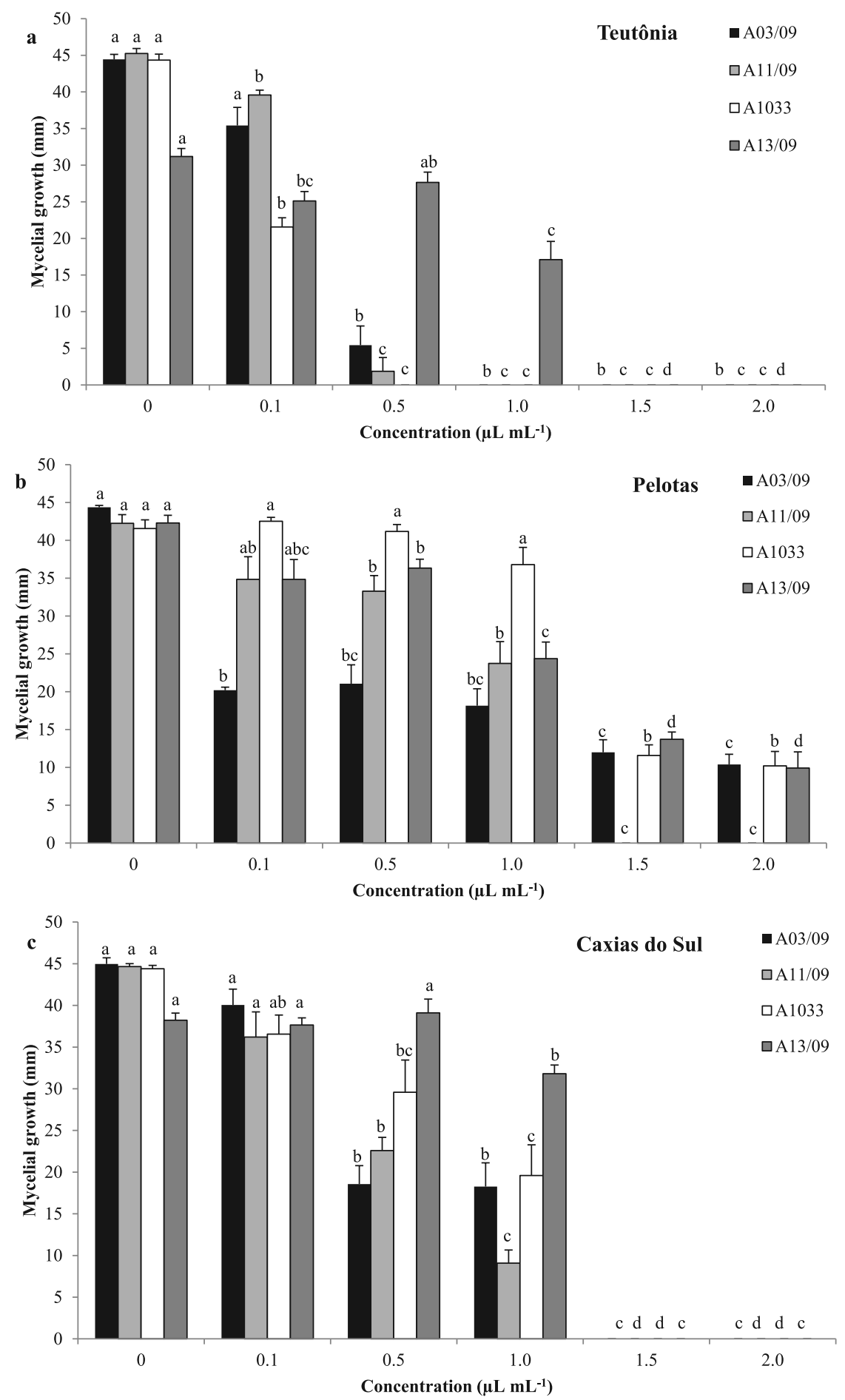

Figure 1 - Effect of different concentrations of three chemotypes of Lippia alba essential oils on the mycelial growth of four Alternaria solani isolates on solid media on the $7^{\text {th }}$ day. a) Teutônia accession - citral chemotype, b) Pelotas accession - camphor/1,8-cineole chemotype, and c) Caxias do Sul accession - linalool chemotype. Values are the mean of ten replicates. Error bars indicate standard error. Letters indicate the comparison between concentrations for each isolate. Means followed by same letter do not differ regarding the Tukey test $(\mathrm{p} \leq 0.05)$. 
The camphor/1,8-cineole chemotype essential oil had a different behavior for each $A$. solani isolate. The growth of A03/09 was significantly inhibited at the $0.1 \mu \mathrm{L}^{-1} \mathrm{~mL}$ concentration, presenting around $50 \%$ of the control growth. However, higher concentrations did not cause the complete inhibition of fungal growth for this isolate. A1033 had its growth significantly inhibited by the two highest concentrations. The growth of A11/09 and A13/09 was significantly reduced at the $0.5 \mu \mathrm{L} \mathrm{mL}^{-1}$ concentration and fungicidal action was observed by the transfer experiment for A11/09 (Fig. 1b).

The linalool chemotype essential oil started its action against $A$. solani at the $0.5 \mu \mathrm{L} \mathrm{mL}^{-1}$ concentration, with the exception of A13/09, which only started to have its growth significantly reduced at $1.0 \mu \mathrm{L} \mathrm{mL}^{-1}$, as of the $7^{\text {th }}$ day growth evaluation. All isolates had a similar behavior at 1.5 and $2.0 \mu \mathrm{L}$ $\mathrm{mL}^{-1}$ concentrations, which completely inhibited fungal growth and differed from the control group, given that all presented fungicidal action (Fig. 1c). However, A13/09 presented a residual mycelial growth for these concentrations on the $14^{\text {th }}$ day (data not shown).

Trials with synthetic fungicide Azoxystrobin (Amistar ${ }^{\circledR}$ Top-Syngenta) at a 50\% concentration and Difenoconazol (Score ${ }^{\circledR}$ Syngenta) at a $25 \%$ concentration were conducted. The former did not demonstrate phytopathogen inhibition, compared to the control group, for all isolates. Difenoconazol inhibited fungal development on all isolates and showed an average of $13.8 \mathrm{~mm}$ diameter of mycelial growth on the $7^{\text {th }}$ day, being comparable to the 1.5 $\mu \mathrm{L} \mathrm{mL}^{-1}$ concentration for camphor/1,8-cineole and linalool chemotypes and $0.5 \mu \mathrm{L} \mathrm{mL}^{-1}$ for the citral chemotype (data not shown) of tested essential oils.

When comparing the different chemotypes of essential oils that were effective in controlling fungal development, the citral (Teutônia) chemotype presented the best performance. Citral significantly inhibited mycelial growth on all isolates at the $0.5 \mu \mathrm{L} \mathrm{mL}^{-1}$ concentration. Essential oils of linalool
(Caxias do Sul) chemotype and camphor/1,8cineole (Pelotas) chemotype were effective as of the $1.5 \mu \mathrm{L} \mathrm{mL}^{-1}$ concentration, although the latter was less efficient (Fig. 2).

PHYTOTOXIC ACTIVITY OF ESSENTIAL OIL VOLATILES ON TOMATO SEEDS

Phytotoxic activity by essential oils was detected at higher concentrations of the evaluated essential oils (Table II). The citral chemotype essential oil was the only one to demonstrate an inhibitory effect towards tomato germination at its highest concentration. Hypocotyl growth was inhibited by the highest concentration of camphor/1,8-cineole chemotype essential oil, presenting a benefic effect on the other concentrations for this parameter (Table II). Regarding root length, the citral chemotype essential oil induced root growth at $0.2 \%$, while the linalool chemotype inhibited said growth (Table II). It is important to consider that essential oils of citral and linalool chemotypes presented fungicidal action at the $1.5 \mu \mathrm{L} \mathrm{mL}^{-1}$ concentration, which did not show any phytotoxic effect $(0.15 \%)$.

\section{DISCUSSION}

The increasing social and economic implications caused by fungi diseases result in a constant effort to produce safer food and to develop new antifungal agents (Feng and Zheng 2007). Essential oils are complex, volatile and natural plant compounds, known for their antiseptic, bactericide and fungicide characteristics (Bakkali et al. 2008). These characteristics enable their use in combating fungi that cause plant leaf diseases, such as the phytopathogen $A$. solani. The essential oils used in this work were obtained from four accessions of Lippia alba, which were originally from different regions of the state of Rio Grande do Sul, Brazil. As was demonstrated in the literature (Tavares et al. 2005, Manica-Cattani et al. 2009, Zoghbi et al. 1998, Atti-Serafini et al. 2002), the composition 

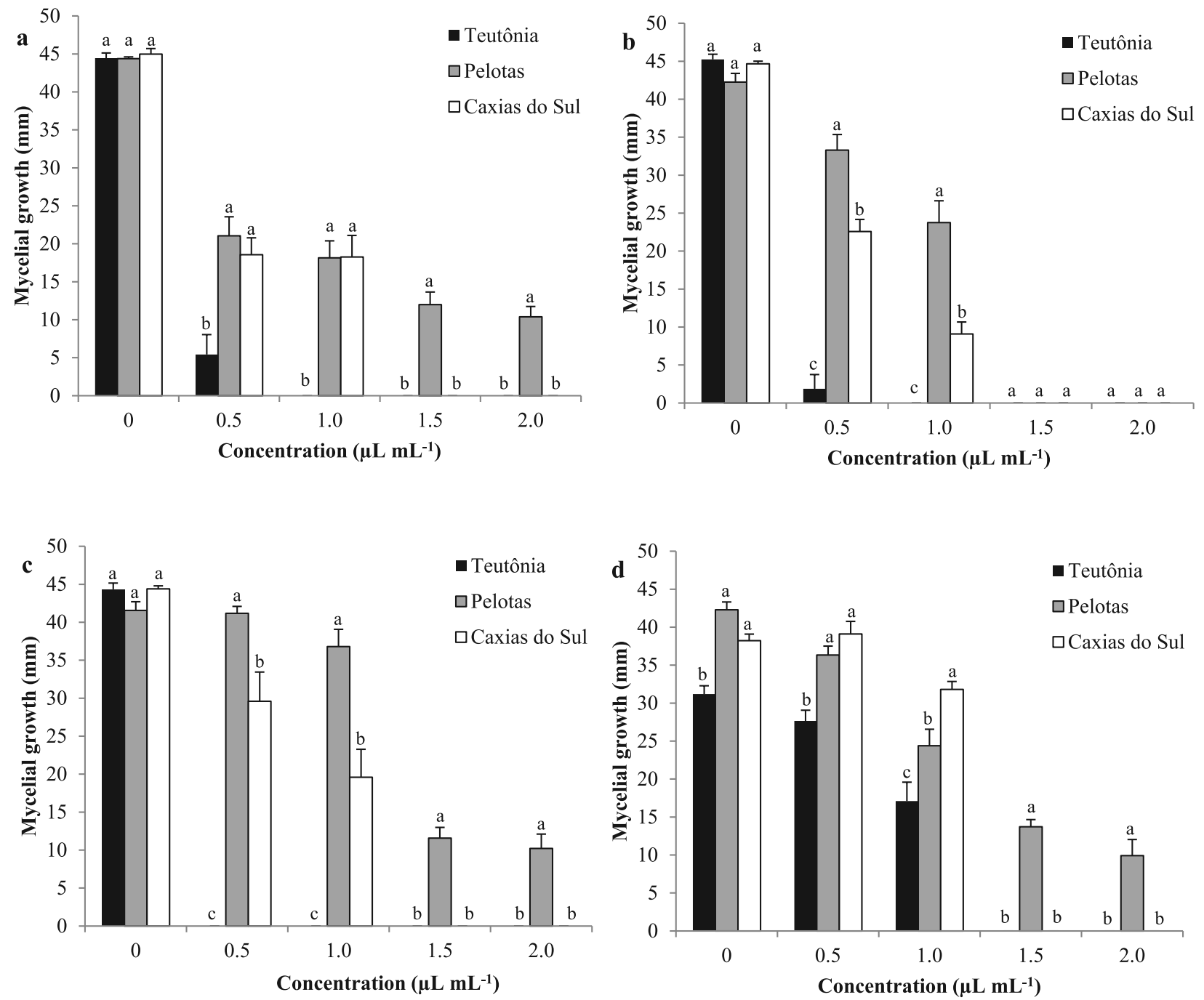

Figure 2 - Comparison between three chemotypes of Lippia alba essential oils on the mycelial growth of four Alternaria solani isolates on solid media on the $7^{\text {th }}$ day. The chemotypes were: Teutônia accession - citral chemotype, Pelotas accession - camphor/1,8cineole chemotype and Caxias do Sul accession - linalool chemotype. a) Isolate A03/09, b) Isolate A11/09, c) Isolate A1033 and d) Isolate A13/09. Values are the mean of ten replicates. Error bars indicate standard error. Letters indicate the comparison between chemotypes for each concentration. Means followed by same letter do not differ regarding the Tukey test $(p \leq 0.05)$.

of $L$. alba essential oils varies, allowing different chemotypes to be identified. Each accession of this work was identified and characterized as a chemotype based on its most abundant compound. Moreover, the four accessions presented essential oil yields that corroborate with yields previously described for the species (Atti-Serafini et al. 2002, Aguiar and Costa 2005, Silva et al. 2006).

In general, essential oils have greater antifungal activity due to a synergistic effect with some active components, being more promising for commercial application than single compounds (Tian et al. 2012). The capacity of the four identified essential oil chemotypes towards inhibiting the growth of $A$. solani isolates was evaluated. We observed that all chemotypes presented inhibitory activity against pathogen growth, with the exception of camphor (Santa Vitória do Palmar). The essential oil with the highest activity was the citral chemotype, followed by linalool and camphor/1,8-cineole (Table III). 
TABLE II

Effect of different concentrations of three chemotypes of Lippia alba essential oils on the germination and growth of tomato seeds.

(Teutônia - citral chemotype, Pelotas - camphor/1,8-cineole chemotype, Caxias do Sul - linalool chemotype).

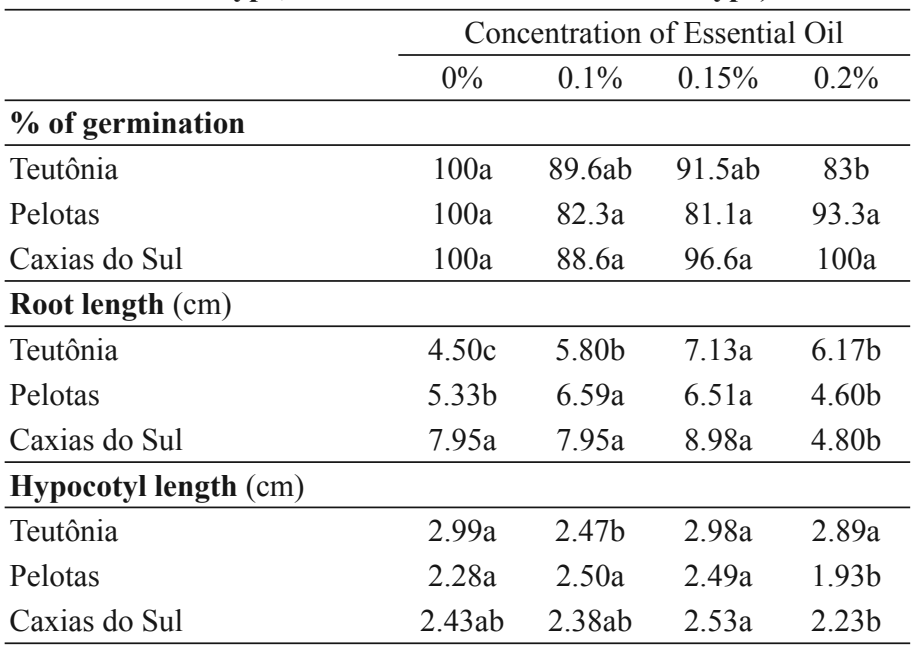

Values are the mean of five replicates. Letters indicate the comparison between essential oil concentrations for each $L$. alba accession. Means followed by the same letter do not differ regarding the Tukey test $(\mathrm{p} \leq$ $0.05)$.

TABLE III

Efficiency of three chemotypes of Lippia alba essential oils on fungicidal activity against Alternaria solani isolates. $\mathrm{IC}_{50}$ values were determined by plotting the concentration of essential oils required to achieve a $50 \%$ reduction of mycelial growth.

\begin{tabular}{lccc}
\hline Isolates & \multicolumn{3}{c}{$\mathbf{I C}_{\mathbf{5 0}}(\boldsymbol{\mu L} / \mathbf{m L})$} \\
& Teutônia & Pelotas & Caxias do Sul \\
\hline $\mathbf{A 0 3 / 0 9}$ & 0.38 & 0.75 & 0.69 \\
$\mathbf{A 1 1 / 0 9}$ & 0.38 & 0.85 & 0.63 \\
$\mathbf{A 1 0 3 3}$ & 0.20 & 1.37 & 0.76 \\
$\mathbf{A 1 3 / 0 9}$ & 0.87 & 1.21 & 1.05 \\
\hline
\end{tabular}

Thus, the antifungal activity demonstrated by the efficiency of the essential oil chemotypes might be related to the chemical composition of the essential oils and their major compounds. On the other hand, the different responses among isolates to each essential oil chemotype should be related to its genetic variability and its degree of pathogenicity (Chaerani and Voorrips 2006).

The essential oils used in this work were oxygenated compounds with hydroxyl groups: a cyclized monoterpene alcohol (1,8-cineole), a non-cyclized monoterpene alcohol (linalool), a monoterpene ester (citral) and a bicyclic monoterpene ketone (camphor). The different results show that the presence of a functional group containing oxygen is important, indicating a relationship between structural and biological activity (Echerrevigaray et al. 2008). Several investigations have been carried out in order to understand the action mechanism of the essential 
oils, but it remains unclear (Ghfir et al. 1997, Knaak and Fiuza 2010).

Essential oils may inhibit the growth of fungi either temporarily (fungistatic) or permanently (fungicide). Three chemotypes used in this study demonstrated significant fungicide action against the phytopathogen Alternaria solani, which corroborates with previously established antifungal activity of $L$. alba essential oils on some plant fungi (Singh et al. 1998, Souza et al. 2005). Other plants presenting the same major compounds in the composition of their essential oils also showed fungicidal activity against other pathogenic fungi, such as L. geminate (citral) (Bhuyan et al. 2010), Leptospermum petersonii (citral) (Lee et al. 2008), Cymbopogon citratus (citral) (Pawar and Thaker 2006), L. nobilis (1,8-cineole) (Simic et al. 2004), Cinnamomun osmophloeum (1,8-cineole) (Wang et al. 2005) and Aniba rosaeodora (linalool) (Simic et al. 2004).

Chemical interactions among plants or microorganisms that cause growth stimulation or inhibition have been described as allelopathy (Rice 1979). This process involves the capacity of one plant species to produce and liberate allelochemicals into the environment, which can be as volatile as essential oils, for example. These allelochemicals can be utilized to improve crop productivity, protect the environment, control weeds, pests and crop diseases (Sousa et al. 2009). The results obtained in this work showed that the concentrations which were used to inhibit the phytopathogen did not present any notable effect on tomato germination and growth. Therefore, the essential oils did not present any phytotoxic effects towards tomato development and could be used to control early blight disease without prejudice to the plant.

\section{CONCLUSIONS}

In conclusion, the essential oils obtained from citral, 1,8-cineole and linalool chemotypes of Lippia alba inhibited the mycelial development of phytopathogen Alternaria solani, presenting fungicidal activity. In addition, they did not show any strong effects on tomato germination and development. All data here presented suggest that these essential oils can be successfully used in the control of early blight disease on tomatoes with the advantage of presenting low environmental impact and low risk concerning the development of resistance by pathogenic microorganisms.

\section{ACKNOWLEDGMENTS}

We would like to thank the technician Dr. Fabiana Agostini for her work on essential oil characterization. The funding for this research was provided by the Conselho Nacional de Desenvolvimento Científico e Tecnológico (CNPq).

\section{RESUMO}

Vários compostos naturais voláteis produzidos pelo metabolismo secundário de plantas têm demonstrado ação antimicrobiana comprovada, permitindo a sua utilização no controle de fitopatógenos. Apresentam também, baixo impacto ambiental em comparação aos pesticidas convencionais. Os óleos essenciais apresentam esses compostos que podem ser encontrados em várias espécies de plantas, tais como Lippia alba (Mill.) N.E. Brown (Verbenaceae). Óleos essenciais de quatro quimiotipos de $L$. alba, caracterizados por seus compostos majoritários, cânfora, citral, linalol e cânfora/1,8-cineol, foram testados contra o fitopatógeno Alternaria solani Sorauer (Pleosporaceae), que causa pinta preta em tomates e é responsável por grandes perdas econômicas na produção. A ação antifúngica dos óleos essenciais foi testada in vitro utilizando meio de cultura batata dextrose ágar (BDA) nas concentrações $0,1,0,5,1,0,1,5$ e $2,0 \mu \mathrm{L} \mathrm{mL}^{-1}$ dos óleos essenciais. $\mathrm{O}$ quimiotipo que apresentou o melhor desempenho foi citral, mostrando inibição significativa em comparação aos outros a partir da concentração $0,5 \mu \mathrm{L} \mathrm{mL}^{-1}$. O óleo essencial do quimiotipo linalol foi eficiente a partir da concentração $1,5 \mu \mathrm{L} \mathrm{mL}^{-1}$. Porém, o quimiotipo cânfora não apresentou ação contra o fitopatógeno. Além disso, os óleos essenciais não tiveram nenhum efeito notável sobre a germinação e crescimento de tomate. Em 
conclusão, estes óleos essenciais apresentaram ação fungicida contra $A$. solani.

Palavras-chave: citral, pinta preta, produto natural, fitopatógeno.

\section{REFERENCES}

ADAMS RP. 1989. Identification of essential oil by ion trap mass spectroscopy. Academic Press Inc., Califórnia, 302 p.

Agostini F, SANTOS ACA, Rossato M, PANSERA Mr, SANTOS PL, SERAFINI LA, MOLON R AND MOYNA P. 2009. Essential oil yield and composition of Lamiaceae species growing in Southern Brazil. Braz Arch Biol Techn 52(2): 473-478.

AGUIAR JS AND COSTA MCCD. 2005. Lippia alba (Mill.) N. E. Brown (Verbenaceae): levantamento de publicações nas áreas química, agronômica e farmacológica, no período de 1979 a 2004. Rev Bras Plantas Med 8: 79-84.

ATTI-SERAFINI L, PANSERA MR, ATTI-SANTOS AC, ROSSATO M, PAULETTI GF, ROTA LD, PAROUL N AND MOYNA P. 2002. Variation in essential oil yeld and composition of Lippia alba (Mill.) N. E. Br. grown in southern Brazil. Rev Bras Plantas Med 4: 72-74.

BAKKALI F, AVERBECK S, AVERBECK D AND IDAOMAR M. 2008. Biological effects of essential oils - a review. Food Chem Toxicol 46: 446-475.

BHUYAN PD, ChUTIA M, PATHAK MG AND BarUah P. 2010. Effect of essential oils from Lippia geminata and Cymbopogon jwarancusa on in vitro growth and sporulation of two rice pathogens. J Am Oil Chem Soc 87: 1333-1340.

CHAERANI R AND VOORRIPS RE. 2006. Tomato early blight (Alternaria solani): the pathogen, genetics, and breeding for resistance. J Gen Plant Pathol 72: 335-347.

ECherrevigaray S, Michelim L, Delamare APL, ANDRADE CP, COSTA SOP AND ZACARIA J. 2008. The Effect of Monoterpenes on Swarming Differentiation and Haemolysin Activity in Proteus mirabilis. Molecules 13: 3107-3116.

FENG W AND ZHENG X. 2007. Essential oils to control $\mathrm{Al}$ ternaria alternata in vitro and in vivo. Food Control 18: 1126-1130.

FIGUEIRA FAR. 2000. Novo manual de olericultura: agrotecnologia moderna na produção e comercialização de hortaliças, Viçosa: UFV, 402 p.

GHFIR B, FONVIEILLE JL AND DARGENT R. 1997. Influence of essential oil of Hyssopus officinalis on the chemical composition of the walls of Aspergillus fumigatus (Fresenius). Mycopathologia 138: 7-12.

Hennebelle T, Sahpaz S, Joseph H and Bailleul $F$. 2008. Ethnopharmacology of Lippia alba. J Ethnopharmacol 116: 211-222.

KHAN R, ISLAM B, AKRAM M, SHAKIL S, AHMAD A, ALI SM, SIDDIQUI M AND KHAN AU. 2009. Antimicrobial activity of five herbal extracts against multidrug resistant (MDR) strains of bacteria and fungus of clinical origin. Molecules 14: 586-597.

KisHORE GK AND PANDE S. 2007. Evaluation of essential oils and their components for broad-spectrum antifungal activity and control of late leaf spot and crown rot diseases in peanut. Plant Dis 91: 375-379.

KNAAK N AND FIUZA LM. 2010. Potencial dos óleos essenciais de plantas no controle de insetos e microrganismos. Neotrop Biol Conserv 5(2): 120-132.

KuROZAWA C AND PaVAn MA. 2005. Doenças do tomateiro (Lycopersicon esculentum Mill.). In: Kimati $\mathrm{H}$ et al. (Eds), Manual de Fitopatologia: Doenças das plantas cultivadas, São Paulo: Agronômica Ceres, p. 607-626.

LEE YS, Kim J, ShIN SC, LEe SG AND PARK IK. 2008. Antifungal activity of Myrtaceae essential oils and their components against three phytopathogenic fungi. Flavour Frag J 23: 23-28.

LOPES CA AND SANTOS JRM. 1994. Doenças do Tomateiro, Brasília: Embrapa Centro Nac. Pesq. De Hortaliças, 67 p.

Manica-CATtani MF, ZaCaria J, PaUletti G, AtTISERAFINI L AND ECHEVERRIGARAY S. 2009. Genetic variation among South Brazilian accessions of Lippia alba Mill. (Verbenaceae) detected by ISSR and RAPD markers. Braz J Biol 69(2): 375-380.

Nerio LS, OliVero-Verbel J AND STASHENKo E. 2010. Repellent activity of essential oils: a review. Bioresour Technol 101: 372-378.

PAWAR VC AND THAKER VS. 2006. In vitro efficacy of 75 essential oils against Aspergillus niger. Mycoses 49: 316323.

RICE EL. 1979. Allelopathy - an update. Bot Rev 45: 15-109.

SATISH S, MOHANA DC, RANHAVENDRA MP AND RAVEESHA KA. 2007. Antifungal activity of some plant extracts against important seed borne pathogens of Aspergillus sp. J Agr Tech 3(1): 109-119.

Silva NA, Oliveira FF, Costa LCB, BIzZo HR AND OLIVEIRA RA. 2006. Caracterização química do óleo essencial de erva cidreira (Lippia alba (Mill.) N. E. Br.) cultivada em Ilhéus na Bahia. Rev Bras Plantas Med 8: 52-55.

Simic A, SOKOVIC MD, RISTIC M, GRUJIC-JOVANOVIC S, VUKOJEVIC J AND MARIN PD. 2004. The chemical composition of some Lauraceae essential oils and their antifungal activities. Phytother Res 18: 713-717.

SINGH SP, RAO GP AND UPADHYAYA PP. 1998. Fungitoxicity of essential oils of some aromatic plants against sugarcane pathogens. Sugar Cane 2: 14-17.

SOUSA SM, SILVA PS, CAMPOS JMS AND VICCINI LF. 2009. Cytotoxic and genotoxic effects of two medicinal species of Verbenaceae. Caryologia 62(4): 326-333.

SOUZA EL, LIMA EO, FREIRE KRL AND SOUSA CP. 2005. Inhibitory action of some essential oils and phytochemicals on the growth of various moulds isolated from foods. Braz Arch Biol Techn 48(2): 245-250. 
TAVARES ES, JUlião LS, LOPES D, BIZZO HR, LAGE CLS AND LEITÃo SG. 2005. Análise do óleo essencial de folhas de três quimiotipos de Lippia alba (Mill.) N.E. Br. (Verbenaceae) cultivados em condições semelhantes. Braz J Pharmacog 15(1): 1-5.

TIAN J, BAN X, ZENG H, HE J, CHEN Y AND WANG Y. 2012. The mechanism of antifungal action of essential oil from dill (Anethum graveolens L.) on Aspergillus flavus. PLoS ONE 7(1): e30147.

WANG S-Y, CHEN P-F AND CHANG S-T. 2005. Antifungal activities of essential oils and their constituents from indigenous cinnamon (Cinnamomum osmophloeum) leaves against wood decay fungi. Bioresour Technol 96 : 813-818.

ZÉTOLA M, LIMA TCM, SONAGLIO D, GONZÁLES-ORTEGA G, Limberger RP, PETROVICK PR AND BASSANI VL. 2002. CNS activities of liquid and spray-dried extracts from Lippia alba - Verbenaceae (Brasilian false melissa). J Ethnopharmacol 82: 207-215.

ZoGHBi MGB, ANDRADE EHA, SANTOS AS, Silva MHL AND MAIA JGS. 1998. Essential oils of Lippia alba (Mill.) N. E. Br. growing wild in the Brazilian Amazon. Flavour Frag J 13: 47-48. 